\title{
The Determinants of Inflation in Emerging Markets and Developing Countries: A Literature Review ${ }^{1}$
}

\author{
Dila ASFUROĞLU²
}

Submitted by: 23.02 .2021

Accepted by: 24.05 .2021

Article Type: Review

\begin{abstract}
A vast literature exists on the determinants of inflation in developed countries whereas the one in emerging markets and developing countries has gained attention at the beginning of 1990s. In this respect, the current paper overviews the empirical studies in order to provide underlying knowledge and common facts on this topic that are valuable for further research and policymakers. The patterns emerge from the results of the existing literature can be summarized as follows. First, inflation is mainly a monetary phenomenon either due to direct or indirect drivers in these countries. However, the significance of the effects from the monetary aggregates are dependent on the countries and periods under study. Secondly, inflation persistence is a major determinant in explaining inflation, suggesting a backward-looking behavior in inflation dynamics for these countries. Lastly, the importance of domestic determinants in understanding inflation has shifted towards external ones implying a greater role for global determinants in the last two decades.
\end{abstract}

Keywords: Inflation, Money Growth Rate, Interest Rate, Exchange Rate, Fiscal Deficit, Global Food Prices, Oil Prices

Atıf: Asfuroğlu, D. (2021). The determinants of inflation in emerging markets and developing countries: A literature review. Anadolu Üniversitesi Sosyal Bilimler Dergisi, 21(2), 483-504.

\footnotetext{
1 This study does not require ethics committee permission.

2 Bahçeşehir University, Faculty of Economics Administrative and Social Sciences Department of Economics, dila.asfuroglu@eas.bau.edu.tr, ORCID: 0000-0003-1650-6711
} 


\title{
Yükselen Piyasalar ve Gelişmekte Olan Ülkelerde Enflasyon Belirleyicileri: Bir Yazın Taraması
}

\author{
Dila ASFUROĞLU
}

Başvuru Tarihi: 23.02.2021

Kabul Tarihi: 24.05.2021

Makale Türü: Derleme

\section{Öz}

Gelişmiş ülkelerde enflasyonun belirleyicileri konusunda geniş bir yazın mevcutken, yükselen piyasalar ve gelişmekte olan ülkelerdeki yazın, 1990'ların başında dikkat çekmiştir. Bu bağlamda, mevcut makale, bu konu hakkında değerli olan temel bilgileri ve ortak gerçekleri, gelecek araştırmalara ve politika yapıcılara sağlamak için ampirik çalışmaları gözden geçirmektedir. Mevcut literatürün sonuçlarından ortaya çıkan örüntüler şu şekilde özetlenebilir. Birincisi, enflasyon, bu ülkelerdeki doğrudan veya dolayl itici güçlerden kaynaklanan, temelde parasal bir olgudur. Bununla birlikte, parasal büyüklüklerin etkilerinin önemi, incelenen ülkelere ve dönemlere bağhldır. İkinci olarak, enflasyon sürekliliğinin, enflasyonu açıklamada önemli bir belirleyici olması, bu ülkeler için enflasyon dinamiklerinde geriye dönük bir davranış olduğunu düşündürmektedir. Son olarak, enflasyonu anlamada yerel belirleyicilerin öneminin dışsal belirleyicilere doğru kayması, son yirmi yılda küresel belirleyicilerin enflasyonu anlamada daha büyük bir rol oynadiğına işaret etmektedir.

Anahtar Kelimeler: Enflasyon, Paranın Büyüme Oranı, Faiz Oranı, Döviz Kuru, Mali Açı, Küresel Gıda Fiyatları, Petrol Fiyatları

\footnotetext{
${ }^{3}$ Bahçeşehir Üniversitesi İktisadi İdari ve Sosyal Bilimler Fakültesi Ekonomi Bölümü, dila.asfuroglu@eas.bau.edu.tr, ORCID: 0000-0003-1650-6711
} 


\section{Introduction}

While the main objective of many central banks in both developed and developing countries is price stability, they set different inflation rate targets in achieving this purpose. The reason behind these unique optimal rates lies on the dynamics of inflation and country-specific characteristics. Considering the importance of understanding the determinants of inflation in developing countries and emerging markets for their volatile dynamics, this study presents mostly the orthodox methodologies and the results of empirical analyses in the existing literature in an attempt to set forth the patterns regarding generally the so-called proximate drivers, by Loungani and Swagel (2001), of inflation in these countries.

Throughout their history, many emerging markets and developing countries have experienced a moderate to high inflation. Inflation began to increase in the 1950s and accelerated immensely in the 1970s and early 1980s; and hyperinflations were experienced in the late 1980s and early 1990s. In the second half of the 1990s, most of these countries managed to lower their inflation rates; and at the beginning of the $21^{\text {st }}$ century, reduced inflation is sustained. However, since mid-2000s, the inflation pressures rose again, mostly because of food and energy prices (International Monetary Fund [IMF], 2008). Inflation had been reduced to double-figure levels in the mid-1990s and by 2000 to single figure levels. This disinflation performance of the 1990s is generally attributed to fiscal consolidation. External developments such as the decline in global inflation and oil prices contributed to descending inflation, as well as the institutional reforms in the form of improved central bank independence (CBI), access to global capital markets; and structural reforms in product, trade and labor markets provided the support to lower the inflation rates (IMF, 2001).

Compare to a vast literature on the determinants of inflation in developed countries, the one in emerging markets and developing countries is rather recent. Therefore, the contribution of this study to the literature is three-fold. First, to bring together the papers in understanding inflation dynamics and to point out to knowledge gaps and changes in the nature of determinants thanks to a historical perspective providing a background for further studies in this topic. Second, to unfold the country- and time-dependent results of these countries and to disentangle how immature this line of research is in developing countries and emerging markets compared to the industrialized countries. Last, to provide policy recommendations to the monetary policymakers of these countries on the account of patterns in determinants of inflation.

Below, there is a survey for inflation determinants of time series and cross-sectional analyses in which all are also categorized according to the geographical location of countries for the sole purpose of the readers easily finding the countries they would like to focus on. Since the country classifications of BIS and IMF do not exactly overlap, the papers overviewed are selected in such a way that countries they study coincide at least one of the classifications. Finally, conclusion section summarizes the results with policy recommendations in the light of common features of inflation for these countries.

\section{Transition Economies: Time Series Analyses}

Koen and Marrese (1995) claim that contemporaneous money is weak in determining inflation for Russia while money growth has the largest impact on inflation 2-4 months later by examining monthly data from January 1992 till November 1994. The similar analysis is conducted by Hoggarth (1996) and Korhonen (1998), concluding that inflation in Russia is a monetary phenomenon. Nikolic (2000) suggests that the money growth is a strong determinant explaining inflation in post-communist Russia. With an inclusion of lagged dependent variable in the analysis covering January 1992-August 1998, considerable influence of inflation inertia is highlighted. Dabrowski et al. (2002) investigate the inflation determinants of Russia using monthly data over January 1996-March 2001. Vector autoregression (VAR) approach estimates a long run relationship between 
the real money balances and interest rate where interest rate decreases the demand for real money balances. Error correction model (ECM) is used for short run examination between inflation, inflation inertia and exchange rate where inflation inertia is indicated to be important in explaining short-term inflation dynamics. In pre-crises sample, exchange rate is shown to be irrelevant whereas it becomes significant in post-crises sample.

Lissovolik (2003) captures the sources of inflation in Ukraine during 1993-2002 relying on a markup and a money market model in a cointegration setting. Exchange rate and wages are strong long-term determinants of inflation while money has a short-term link with inflation; and the role of relative price variability in inflation is supported. Siliverstovs and Bilan (2005) explore the interrelationship among inflation, wage and money growth, and devaluation expectation via variance decompositions (VD) and impulse response functions (IRF) for Ukraine. Using monthly data spanning over January 1996-November 2003, they show that the changes in devaluation expectations are the main driving source of price changes while money supply has negligible effects on inflation; and find an evidence for substantial inflation inertia.

\section{Transition Economies: Cross-Sectional Analyses}

Coorey et al. (1996) estimate an equation for inflation from an analytic model for the pool of 21 countries. They suggest that money and wage growth have a substantial impact in explaining inflation while real appreciation does not have a significant impact. The effect of relative price variability is found to be sensitive to the region and sample period with a sizable effect during high inflation and a small impact during modest inflation. Inertia and downward price rigidity are argued to be important in explaining inflation when it is at moderate levels. Fischer et al. (1998) use exchange rate regime, fiscal balance and structural reforms as explanatory variables to understand inflation dynamics in 25 transition countries with the sample period of 1992-1996. They find that lower fiscal deficit, fixed exchange rate regime and structural reforms help stabilizing high inflation in these countries. Kutan and Brada (1999) explore the moderation of inflation in Czech Republic, Poland and Hungary at the end of the 1990s. Their results indicate that past inflation and import price movements are dominant contributors to inflation while the money supply and wage growth are unimportant contributors in the short run. The role of foreign prices demonstrates that the moderation of inflation in these countries are driven exogenously, stemming from a general global deflation and a decline in both global energy and commodity prices.

Antczak (2003) analyzes twelve transition countries ${ }^{4}$ from Central, Eastern Europe and former Soviet Union covering 1990-1997. Money multiplier, fiscal balances, money velocity and current account deficit are checked as the monetary aggregates explaining inflation. Correlation analysis indicates that changes in the money supply explains the inflation more and directly when expansionary policy is induced by monetization of fiscal deficit in high and very high inflation periods. On the contrary, the relationship becomes weaker during moderate and low inflation times. Iwasaki and Uegaki (2017) examine the relationship between CBI and inflation in transition economies with a meta-analysis where 122 estimates are collected covering 1997-2014 from transition studies. Based on the distribution of the partial correlation coefficient, they conclude that CBI causes disinflation suggesting a negative impact of CBI on inflation.

\section{Asian Economies: Time Series Analyses}

Model in Lim and Papi (1997) contains the goods, labor, money and external sectors to analyze the determinants of inflation in Turkey during 1970-1995, where the goods market inclines the equilibrium condition for the prices in the long-run while short-run dynamics of prices are affected by the disequilibria in

\footnotetext{
${ }^{4}$ Croatia, Czech Republic, Hungary, Poland, Slovakia, Slovenia, Estonia, Kazakhstan, Latvia, Lithuania, Russia, Ukraine.
} 
labor, money and external markets. According to their findings, Turkish inflation is driven by monetary variables, namely money and exchange rate; inertial factors are quantitatively significant; and public deficit has an important effect on inflation. Cheng and Tan (2002) apply vector ECM (VECM) analysis for Malaysia with quarterly data covering 1973-1997, considering variables, such as money supply, interest rate, exchange rate, trade balance, capital inflows and external prices. They conclude that external causes, especially the rest of the ASEAN's inflation and exchange rate, have predominant effects on inflation. Among the domestic factors, private consumption and government expenditure are the most important determinants of inflation with a less significant impact than that of external causes. Grigorian et al. (2004) explore the monetary transmission channels in Armenia under money, labor and foreign exchange markets, where inflation is assumed to be caused by imported inflation (i.e. inflation in trading partners), excessive money growth and wage pressures. Covering the period from January 1996 to June 2003 and using the equilibrium conditions from three markets, cointegration relationships and ECM are utilized for long- and short-run dynamics. Prices respond strongly to the disequilibria in the exchange rate market while the pass-through of excess money and wage pressures in excess of labor productivity are found to be insignificant.

Khan and Schimmelpfennig (2006) claim that the recent increase in inflation over January 1998-June 2005 in Pakistan is due to the increases in the wheat support price, leading to a monetarist against structuralist-driven inflation explanation. Incorporating the wheat support price into the general open-economy monetary model, the estimation of VECM suggests that broad money growth and private sector credit growth determine inflation while the wheat support price influences inflation only in the short run. Bonato (2007) concentrates on the relationship between inflation and nominal variables for Islamic Republic of Iran. Based on a small open economy IS-LM model for the quarterly period of 1988-2006, estimated ECM indicates that money growth has a predominant role in determining inflation both in the short- and long-run; and there exists a long-run relationship between the price level and money, its rate of return, exchange rate and real output.

Duma (2008) focuses on the effects of external shocks in Sri Lanka using monthly data covering 2003-2007. In order to estimate the pass-through effects, VAR is used including output gap for demand shock; oil price inflation to proxy international supply shocks; and change in the nominal exchange rate as an exchange rate shock. The results suggest that while depreciation of the local currency and import price shocks affect inflation immediately and positively, oil price shocks have an immediate but negative effect on inflation. Additionally, pass-through from exchange rate and import price shocks to prices are positive whereas that of oil price shocks are negative and small. Since the analysis checks for both consumer and wholesale prices, the comparison of the resulting effects on these indices implies that the pass-through of external shocks to wholesale prices is more severe compared to that of consumer prices. Pavlavani and Rahimi (2009) assume that endogenous factors such as expected inflation, imported inflation, liquidity, GDP and exchange rate determine inflation in Iran. Relying on autoregressive distributed lag (ARDL) approach covering 1971-2006, their estimations suggest that inflation expectation is the most significant determinant of inflation, with exchange rate, imported inflation and liquidity being other effective factors both in the short- and long-run.

Khan and Gill (2010) investigate money supply, budget deficit, exchange rate, inflationary expectations, interest rate, value of imports, wheat support price; and support prices of sugarcane, cotton, rice and wheat as causes of inflation in Pakistan focusing on four different price indicators. In the period of 1971-2006, inflation is not affected by fiscal deficit, money supply and wheat support price while exchange rate depreciation, increase in the value of imports and inflation expectations surge inflation in the long run with inflation inertia being the strongest contributor. The impact of interest rate on inflation is negative, yet insignificant whereas that of support prices of sugarcane, rice, wheat and cotton together is positive and significant. In a VAR framework utilizing IRF and VD with quarterly data spanning 1991-2008, Patnaik (2010) indicates that the 
drivers of inflation in India is a mix of demand and supply side factors. Specifically, volume of demand, which has the most significant effect, money supply and external influences on domestic prices are the main drivers of inflation with the last two determinants having short-run impact. Bhattacharya (2013) focuses on the monetary policy transmission mechanisms in Vietnam in order to explain the experienced higher inflation compared to other Asian emerging markets. Following a price-taking small open economy model where inflation is a weighted average of changes in tradable and non-tradable good prices, inflation becomes a function of aggregate demand/real output, money supply, nominal effective exchange rate, nominal interest rate and foreign price inflation. Over 2004Q1-2012Q2, estimated VAR suggests that movements in the nominal effective exchange rate are the key factors in the short-run whereas over the medium-run, GDP growth and growth in credit are the main drivers of inflation.

In their time varying-parameter (TVP) structural VAR (SVAR) model for India covering Q1: 1996-1997-Q3: 2013-2014, Mohanty and John (2015) conclude that crude oil prices, output gap, fiscal policy and monetary policy (i.e. money rate) exhibit significant time variation. Crude oil prices and exchange rate are important in explaining inflation while on average the output gap is insignificant with an asymmetric effect on inflation. The fiscal deficit contributes to inflation in 2011-2012 while the monetary policy affects inflation only after 2005-2006. Alam and Alam (2016) use cointegration method with data from 1989-2013 for India. Their bound test analysis suggests that increased money supply, supply bottlenecks and depreciation of the local currency cause inflation to rise in the long-run. In the short run, domestic factors such as lower actual output than potential output and money supply are more significant in raising inflation than external factors. Wen et al. (2019) study the dynamic effects of crude oil prices on China's inflation by using TVP VAR over January 1996 to June 2017. Inflation in China is affected positively by international crude oil price and money supply shocks in the short run. Chiang et al. (2021) investigate microeconomic sources of inflation dynamics in China accounting for local pricing power of certain markets and sectors, sectoral and regional stickiness which resulted from rural-urban divide by policies in China on top of macroeconomic drivers. After applying shiftshare decomposition, VDs calculated from SVAR over 1994-2015 indicate that sectoral shocks (i.e. sectoral price rigidities) are the most important factor in explaining urban inflation in the short-run whereas it is the national inflation in the long-run. Sectoral and local pricing power effects are the most crucial factor for rural inflation.

\section{Asian Economies: Cross-Sectional Analyses}

Jongwanich and Park (2009) examine nine Asian countries covering the quarterly period of 1996-2009 with VAR approach. They conclude that excess aggregate demand with the proxy of output gap and inflation expectations account for $15 \%-30 \%$ and $30 \%-60 \%$ of the variability in inflation respectively; and external food and oil price shocks explain less than $30 \%$ of CPI inflation. Osorio and Unsal (2011) disentangle the contributions of domestic, regional and global factors to inflation for 33 countries from Asia and Pacific ${ }^{5}$ region using Global VAR (GVAR) model covering 1986-2010. To see how the inflationary processes of Asia have altered, they estimate SVAR model for each country in 1986-99 and 2000-09. They indicate that supply (i.e. commodity prices) and monetary shocks have been the main sources of inflation in Asia for the last two decades. Specifically, changes in exchange rates explain about $15 \%$ of fluctuations in inflation; and changes in money supply and interest rates explain about $25 \%$. However, the impact of these shocks has faded away, particularly in economies that have flexible exchange rate regimes and relatively clear monetary aims. The role of supply shocks has diminished slightly in recent years whereas the role of output gap has risen. Finally, they claim that inflation fluctuations are driven predominantly by domestic factors accounting more than $60 \%$ while global factors account for about 30\%. Bhattacharya (2013) uses Generalized Method of Moments (GMM)

\footnotetext{
${ }^{5}$ This paper incorporates the countries such as New Zealand, Australia with the countries, for instance Malaysia and Thailand in the analysis.
} 
covering the period 2004Q1-2012Q2 for EMEs (China, India, Indonesia, Malaysia, Philippines, Sri Lanka and Thailand) after Vietnam comparison. With the inclusion of lagged variables, domestic and external factors, the results indicate that contemporaneous movements in import prices and past inflation are important determinants of inflation for all these countries whereas lagged growth rates of GDP or of money supply, lagged nominal interest rates and lagged movements in the nominal effective exchange rate play no role in explaining inflation.

\section{African Economies: Time Series Analyses}

In Nigeria with ECM covering the period of 1962-1993, Moser (1995) shows that money growth that is brought by fiscal deficit is the main driving force of inflation; and devaluation of the currency together with agroclimatic conditions are the other important determinants of inflationary pressure. Ubide (1997) decomposes inflation into components in Mozambique and explores the transition mechanisms via autoregressive integrated moving average (ARIMA) model during 1990-1996 using open economy definition of inflation. In the longrun, inflation is driven by monetary expansion, depreciation of exchange rate and unforeseen events in agricultural sectors while inflation inertia is insignificant. Assuming that inflation is determined by the equilibrium in the money market; Blavy (2004) analyzes quarterly data covering September 1991-March 2003 for Guinea via cointegration and ECM. The results show that the significant long-run relationship between inflation and money growth has boosted in recent years; and inflation persists over time in the short-run.

Nassar (2005) finds a long-run relationship between domestic prices, real income, broad money and foreign interest rates for Madagascar using quarterly data over 1982-2004, based on a monetary disequilibrium model with an open economy. While exchange rate movements have significant effects and inflation inertia is important, foreign interest rates are statistically insignificant in the long-run. Diouf (2007) focuses on structuralist hypothesis, monetarist and external theories for Mali. The estimation of ECM with quarterly data over 1979-2006 shows that supply-side constraints, namely average national rainfall represents the cereal production, have large and significant effects on inflation by decreasing it. Real appreciation of the domestic currency decreases inflation in the long-run more significantly than the increasing effect of excess money supply, suggesting the monetary and imported long-run drivers as the main sources of inflation in Mali whereas real income growth is suggested as the short-run determinant. Based on a monthly data over 20012006, Gottschalk et al. (2008) estimate SVAR for Sierra Leone showing that increasing money growth, higher oil prices and nominal exchange rate depreciation cause an increase in inflation in Sierra Leone ${ }^{6}$. Wolde-Rufael (2008) investigates the causal link among budget deficit, money supply and inflation for the period of 19642003 in Ethiopia conducting cointegration tests and VD. The results indicate that fiscal deficit and money supply contribute to inflation without money supply being interfered by budget deficit.

Klein and Kyei (2009) identify the factors that contribute to the sharp decline in inflation in Angola with quarterly data over 1997-2007. The results from VECM indicate a significant long run relation between inflation and exchange rate; that money growth affects inflation with a lag as it first triggers demand pressure. Since the large share in inflation basket is devoted to imported food items, international non-fuel commodity prices have a strong impact on inflation in Angola. With ARDL, Adu and Marbuah (2011) employ a small open economy definition for inflation for Ghana over 1960-2009. Their results show that without a shift of the importance of the determinants during the sample period, real output, broad money supply, fiscal deficit, nominal exchange and nominal interest rates are important factors in explaining inflation with output growth having the strongest impact. Using quarterly data over 1983-2009 for Chad, Kinda (2011) relies on a small

\footnotetext{
${ }^{6}$ They address a problem about an important omitted variable, specifically government financing. Their concern refers to the fact that fiscal policy and monetary policy intervene and sometimes constrain each other. Yet, due to the data limitations, they regard this incompleteness in the effects from monetary policy shocks as a shortcoming, but not crucial.
} 
open economy IS-LM model in VECM. Supply-side constraints (i.e. rainfall), public spending and external factors (i.e. changes in trading partner prices and exchange rate) are the main causes of inflation. Conducting SVAR confirms the effects of rainfall, foreign prices, exchange rate and public spending with an addition of persistence of inflation.

Using a monthly data over 2000-2012, Durevall et al. (2013) find that the international food and goods prices determine the long-run inflation in Ethiopia. Food inflation is affected by agricultural supply shocks in the short run, deviating from long run price trends; and money supply plays a role in driving short run non-food inflation. According to the results of Alkoum and Agil (2013), which uses ARDL over 1980-2011 for Libya, money supply, real income and imported inflation are the most significant drivers of inflation both in the short- and long-run. Exchange rate, output gap and inflation expectation also contribute to inflation with descending impacts. Bane (2018) incorporates monetarist and structuralist views for Ethiopia applying ARDL over the period 1975-2015. The paper shows that the money supply and interest rate are the major monetary determinants of inflation with the former having approximately one-to-one effect. Since structural factors, such as real GDP growth, are also indicated as important drivers both in the short- and long-run, inflation in Ethiopia is not merely a monetary phenomenon.

\section{African Economies: Cross-Sectional Analyses}

Barnichon and Peiris (2007) build up measures of output gap and real money gap via panel cointegration regressions in order to estimate the expectation-augmented Phillips curve in an attempt to explore the relationship among output and real money gaps and inflation in seventeen Sub-Saharan Africa (SSA). With panel GMM covering the years from 1960 to 2003, they claim that both output and real money gaps have an important role in inflation with the latter having larger impact than the former; and excess money have a larger role than excess output in explaining inflation. Thorton (2008) demonstrates that there exists a weak (strong) long-run relation between money growth and inflation for the countries with money growth and inflation below $10 \%$ (much higher than 10\%), based on the quantity theory of money using 36 African countries over 1960-2007.

In 22 Sub-Saharan countries from 1980-2005 applying VAR, Baldini and Poplawski-Ribeiro (2011) find that the nominal public debt, as proxied by money growth, plays an important role in inflation; and fixed exchange rate is related with lower inflation. Using VAR for four CEMAC members (Cameroon, the Central African Republic, Gabon, the Republic of Congo) from 1996 to 2010, Caceres et al. (2011) argue that inflation is driven mainly by government policies, namely controlled prices which direct the spillover from international market prices into domestic prices, government expenditure and global food and energy commodity prices. Money supply has insignificant effects in the region; and exchange rate movements have indirect effects on inflation through import prices. African Development Bank (2011) elaborate the underlying reasons of recent high inflation rates Ethiopia, Kenya, Tanzania and Uganda spanning 1961-2010 by taking into account the characteristics of each country. The main source of short-run inflation in Ethiopia and Uganda is found to be money growth while in Kenya and Tanzania, oil prices seem to be the main driver of inflation with an increasing impact coming from money supply in recent years. In general, money supply, world food and oil prices are the significant factors in explaining inflation rates in these countries. Durevall and Sjö (2012) assess the recent upright trend of inflation in Ethiopia and Kenya over 1999-2011 using ECM with monthly data. Their results show that while exchange rates and world food prices have a long run impact, agricultural supply shocks and money growth have short and medium run effects on inflation; and inflation is driven substantially by its past realizations. 
With overall price levels as a weighted average of tradable and non-tradable goods and incorporated money market equilibrium, Oladipo et al. (2013) estimate VAR and VECM covering the period between 1970Q1 and 2010Q4 for Guinea Bissau, Ghana, Gambia, Guinea, Nigeria and Sierra Leone. Their results suggest that money supply, income, exchange rate movements and foreign prices play significant role in the long-run; and except foreign prices, other drivers remain as significant determinants of inflation in the short-run. Portillo (2018) studies the main sources of inflation in the CEMAC both empirically and theoretically. Accounting that due to large oil exporter countries, variations in oil revenues may affect not only aggregate demand and fiscal policy but also inflation due to pegged exchange rate in this monetary union, the study employs a semi-structural VAR. Fiscal and commodity price shocks are found to drive inflation with monetary policy having a passive role in affecting inflation.

Nguyen et al. (2015) assess the fact that policy shifts, the integration with the global world may have changed the presumption that the inflation in SSA countries are led by supply shocks. They first estimate Global VAR model for 65 countries, including 33 SSA countries, covering quarterly data over 1988-2013 in order to investigate the reasons of inflationary pressure. Secondly, they search for an evidence of structural break of how the inflationary process has changed over time in 1988-98 and 1999-2013. Over the last 25 years, shocks to exchange rate, monetary variables and domestic supply shocks are shown to be the most important determinants of inflation. Country characteristics, such as vulnerability to weather shocks, economic importance of agriculture, oil and food imports, trade openness and policy regime are also highlighted for driving inflation. However, over the last decade, the role for global oil and foods shocks, domestic demand shocks, shocks to output as well as inflation spillovers from other countries have increased whereas the role of exchange rate shocks, domestic supply shocks and monetary variables have decreased.

\section{American Economies: Time Series Analyses}

Williams and Adedeji (2004) investigate the effects of the money and traded-goods market disequilibria in Dominican Republic during 1991-2002. The results from quarterly observations indicate that the disequilibrium in the money market plays a significant role on inflation while the disequilibrium in the traded goods market does not. Furthermore, ECM shows that changes in real output, exchange rate, monetary aggregates and foreign prices drive inflation in the short-run. In their quarterly observation analysis over 1983Q1-2001Q4, Bailliu et al. (2003) apply a mark-up, a money-gap model and a Phillips curve to explain the major determinants of inflation in Mexico. A mark-up model treats inflation as a cost-push phenomenon where the price level is determined by a long-term constant mark-up over costs. A money-gap model views inflation as a monetary phenomenon where changes in the price level occurs for correcting monetary disequilibria. Money gap is defined as the difference between the actual money supply and the estimated longrun money demand; and a positive money gap, in which the stock of money is above the long-run demand for money, suggests rising inflationary pressures. Phillips curve approach claims that inflation arises from real factors, in particular imbalances between aggregate demand and supply where a decrease in unemployment rate suggests a boost in excess demand, which causes an upward pressure on nominal wages affecting inflation expectations; and in turn inflation. Among all, the mark-up model performs the best for explaining the dynamics of inflation in Mexico and the exchange rate is found to be the predominant driver.

In their mark-up model for Paraguay, Monfort and Peña (2008) calculate the prices as a weighted average of unit labor cost, other domestic inputs and foreign prices. Using cointegrated VAR and VECM with quarterly data over 1991-2007, oil and administered prices are found to be insignificant while the exchange rates of the main trading partners as a proxy for imported inflation and unit labor costs are shown to be significant in explaining inflation. In the monetary theory model where they consider currency in circulation and broad money as explanatory variables, the former appears to be the predominant monetary aggregate for inflation 
movements in the long-term, so as inflation inertia, stemming either from inflation expectations or from wage indexation. D'Amato and Garegnani (2009) estimate a hybrid New-Keynesian Phillips curve for Argentina where both backward- and forward-looking rules of price setting together with a marginal cost measure (i.e. aggregate labor income share) are considered. They incorporate nominal devaluation and foreign inflation to the model in order to account for small open economy dynamics. With a GMM estimation covering 19932007, their results demonstrate that nominal devaluation and foreign inflation have a significant effect on inflation, with the latter accounting for more impact. Both backward- and forward-looking components are important in determining inflation dynamics in Argentina, with the former having larger effects.

\section{American Economies: Cross-Sectional Analyses}

Capistrán and Ramos-Francia (2006) estimate varying degree of inflation persistence across ten largest Latin American economies ${ }^{7}$ covering the period 1980-2006; and find that the region has very high persistence in inflation. De Mello and Moccero (2008) find that monetary policy has a significant role in anchoring inflation expectations in Brazil, Chile, Colombia, and Mexico, which is shaped by inflation targets, indicating long-term relationships between expected inflation, interest rate and the inflation target. Using the multivariate GARCH methodology, spillover effects from interest rate to inflation expectations are found for these countries except Chile.

\section{Countries of Specific Categorizations: Cross-Sectional Analyses}

Using pooled VAR estimations for 53 developing countries from Africa, Asia, Mediterranean and South America over 1964-1998, Loungani and Swagel (2001) find that inflation persistence plays a predominant role, accounting about $50 \%, 50 \%, 70 \%$ of variation in inflation in Mediterranean, Asia and Africa respectively. However, its role is smaller (i.e. 5\%) for South America and 10\% when all the countries are considered. The coefficient of inflation inertia is greater for fixed exchange rate countries than for floating rate countries. Money growth is the second most important determinant of inflation when inflation inertia is the dominant factor. Its contribution to inflation is less important in fixed exchange rate regimes than in non-fixed regimes. Both fuel and non-fuel commodity prices have significant impacts on inflation in fixed exchange rate regimes among these developing countries.

Mohanty and Klau (2001) test demand and supply side factors combining wage and mark-up price equations together with Phillips curve, concentrating 1990s because of the data limitations, in $14 \mathrm{EMEs}^{9}$ over the 1970s1990s. They find that exogenous supply shocks (i.e. food price shocks), are the most common drivers, with exchange rate being the next. Food prices are also significant in variability of inflation. The demand factors (i.e. output gap and excess money) and wage growth as supply side factor play significant role in affecting inflation. Other supply side factors (i.e. exchange rate, import prices) and agriculture shocks are also significant main drivers of price movements in EMEs whereas oil price shocks are found to have a weak effect on inflation. Finally, they point that persistence of inflation explains a large proportion of both the average and variation in inflation. IMF (2001) finds a significant long-run relationship between the size of government deficit and inflation in 23 EMEs using dynamic panel regression analysis over 1970-1999, suggesting that inflation is positively associated with fiscal deficit and negatively with the size of inflation tax base ${ }^{10}$. Additionally, world inflation and changes in oil prices are found to be significant while there is no statistical relationship between

\footnotetext{
7 The countries under consideration are Argentina, Bolivia, Brazil, Chile, Colombia, Ecuador, Mexico, Peru, Uruguay and Venezuela.

${ }^{8}$ Contrary to the result of Crowley (2010), see below.

9 The countries considered by the study: Brazil, Chile, the Czech Republic, Hungary, India, Korea, Malaysia, Mexico, Peru, the Philippines, Poland, South Africa, Taiwan (China) and Thailand.

${ }^{10}$ The relationship is tested with the inclusion of other drivers of inflation by excluding the countries that experienced hyperinflation episodes and found to be robust.
} 
fixed exchange rate regime and inflation; and the negative relationship between openness and inflation becomes insignificant when fiscal imbalance is introduced.

Catão and Terrones (2001) search for an evidence of "unpleasant monetarist arithmetic" of Sargent and Wallace (1981) for a panel of 23 EMEs during 1970-2000. Their long-run relationship between fiscal deficit and inflation is brought by a general equilibrium model, which relates fiscal deficit, money demand, money supply and inflation. Nesting the theoretical model on ARDL, they find that 1 percentage point decrease in fiscal deficit to GDP ratio decreases inflation by 2-7 percentage point. Since the result remains the same, when very high- and hyper-inflation countries are excluded from the sample ${ }^{11}$, fiscal deficit is concluded to have a positive significant relationship with inflation. Oil price changes and world inflation are important and significant in determining inflation while openness to trade and the exchange rate regime movements provide no evidence for affecting inflation. Domaç and Yücel (2005) investigate the common factors and political determinants contributing to the starts of inflationary episodes in 15 EMEs $^{12}$ covering 1980-2001. From the political perspective, populist view of inflation suggests that polarized and fragmented governments, which have electoral uncertainty and disagreements between policymakers, are more prone to levy inflation tax. On the other hand, the state-capture approach argues that wealthy and powerful elite may derive personal benefit from inflation so that the price instability is due to the will of incumbent politicians or the elite, contrary to the demand by the public for inflationary financing. While this view suggests that price stability can be achieved by promoting democratic accountability, the former conjecture argues that for price stability, autonomous and consolidated governments are needed. Their pooled probit analysis indicate that inflation episodes are triggered by output gap, change in food production index and in oil prices. Democracy and durability of the regime measures are negatively correlated with inflation starts, supporting the state-capture view. While an increase in GDP growth above trend, negative agricultural shocks and decrease in budget surplus raise the probability of inflation starts, an increase in capital flow relative to GDP and a more democratic environment decrease the probability of inflation starts in these EMEs.

Kwon et al. (2006) consider the role of public debt rather than the budget deficit to assess "unpleasant monetarist arithmetic" relying on forward-looking fiscal-monetary models of inflation. First, it is because monetization expectations and wealth effects of public debt can arise regardless of the size of the budget deficit; secondly, the size of the budget deficit can be quite different from the public debt due to debt-indexation, nondebt financing and exchange rate movements (IMF 2003). Utilizing GMM estimation for 71 developing and developed countries spanning 1963-2004, they find a strong and positive impact of debt growth on inflation in developing and non-major advanced economies, with greater impact for indebted developing countries. The significant link exists even when money growth, real output growth, currency depreciation and output gap are controlled. Furthermore, the response of inflation to debt is larger and significant under a floating regime than a fixed exchange rate regime. As an application, they also confirm the significance of public debt-inflation link in Jamaica with a VAR approach. Borio and Filardo (2007) pose a more "globe-centric" approach considering the changes in the trend of inflation and in sensitivity of inflation responses to traditional determinants, especially since 1990s. Their country-centric approach assumes that inflation is determined by excess demand, wage, exchange rate and import prices which captures international effects whereas the globe-centric approach considers foreign prices, global excess demand pressures and factor mobility. Extended backward-looking Phillips curve with a global measure of economic slack, calculated as weighted average of international output gaps, over 1985-2005 covering industrial and emerging market countries suggest that global factors have

\footnotetext{
${ }^{11}$ Fischer et al. (2002) argue that the relationship is significant for countries that experience very high inflations.

${ }^{12}$ The countries covered by the paper: Argentina, Brazil, Colombia, India, Indonesia, Israel, Korea, Malaysia, Mexico, Peru, the Philippines, South Africa, Thailand, Turkey, and Venezuela.
} 
become more important relative to domestic ones. In some countries, the explanatory powers of global factors dominated that of domestic output gaps as one of the key determinants of domestic inflation.

Habermeier et al. (2009) analyze the inflation pressures and monetary policy responses to rising inflation due to the food and oil price shocks using pooled OLS, GMM for 49 EMEs and developing countries covering monthly data during January 2005-June 2008. Monetary policy tightening is found to be related with a decrease in inflation while aggregate demand pressures and higher commodity prices increase inflation. Observed surge in inflation is attributed to aggregate demand pressures, proxied by credit growth, and rise in food and energy prices while food and oil inflation are found to be insignificant in affecting inflation even considering their large share in CPI basket. A negative relationship between rise in inflation and exchange rate appreciation is observed. Currency appreciations under more flexible exchange rate regimes, greater degree of CBI and credibility are found to be associated with lower inflation. Increasing capacity constraint, inflation persistence and tighter labor markets are found to contribute to inflationary pressures with second round effects. In the Middle East, North Africa, and Central Asia (MENACA) region ${ }^{13}$, regional inflation had a downward trend from 1996 until 2000, which was reversed since 2000. Crowley (2010) aims to understand the reasons behind this shift; and finds a positive and significant correlation between inflation and changes in non-fuel commodity prices. Inflation inertia is found to be the most significant factor. The effects of the percent change in the exchange rate and broad money supply are proven to be positive and significant. The strength of US dollar is related to a lower inflation; with the level being more important than the change. However, the effect of change in fuel prices, real economic growth and import prices on inflation are suggested to be insignificant.

While backward-looking Phillips curves put too much emphasis on inertia, forward-looking Phillips curves have difficulties in explaining the persistence and responsiveness of inflation to monetary policy shocks. New Keynesian models are also not plausible to account for open-economy considerations, such as trade openness' affecting price setting behaviors of firms through marginal production costs. To solve this problem, Agénor and Bayraktar (2010) estimate contracting models of the Phillips curve for eight middle-income developing countries ${ }^{14}$, focusing on the impact of openness, borrowing costs, the role of marginal production costs and factor substitution between labor and imported inputs. In all specifications, they include the real exchange rate, the relative price of imported intermediate goods in terms of wage (i.e. a measure for the degree of factor substitution), imported oil prices and lending costs to account for the possibility that firms may need to borrow. Based on two-step GMM, their results indicate that one lagged and one lead inflation rates are highly significant and have a positive effect on the current inflation in all countries with backward-looking behavior being a more important component in explaining inflation. The lending rate and output gap positively affect inflation. World oil prices and relative input prices are found to have a limited impact on inflation. Lim and Sek (2015) explore the long- and short-run relationship between money supply, imports, national expenditure, GDP growth and inflation in countries of high inflation ${ }^{15}$ and low inflation by applying ARDL and ECM covering 1970-2011. Money supply and national expenditure are found to have significant effects on inflation in the long-run with the former having negative and the latter having positive impacts in high inflation countries. On the contrary, none of the variables is shown to have an impact on inflation in the short-run in these countries.

\footnotetext{
${ }^{13}$ It is important to approach these conclusions with caution as Kuwait, Qatar, Saudi Arabia, United Arab Emirates are also included in the sample. Yet, it is noted that regrouping the countries into subgroups as major oil exporter, moderate oil exporter, and countries that export little or no oil does not change the pattern of inflation in the region.

${ }^{14}$ Chile, Colombia, Korea, Malaysia, Mexico, Morocco, Tunisia, and Turkey.

${ }^{15}$ Iran, Argentine, Uruguay, Sudan, Burundi, Colombia, Ecuador, Ghana, Iceland, Indonesia, Israel, Mexico, Turkey.
} 
Deniz et al. (2016) investigate money growth, budget balance, real effective exchange rate, real wages, GDP growth and output gap as determinants of inflation under various categorization of countries, in which (non)inflation targeting emerging markets and industrialized countries are considered. Using fixed effect and GMM estimations, they show that inflation inertia has a significant impact on inflation in 17 EMEs with those inflation-targeting countries having higher coefficient than the non-inflation targeting countries. Appreciation of domestic currency, budget balance and GDP growth have a negative impact on inflation whereas output gap, money growth and real wage have a positive effect on inflation. Parker (2017) studies the relevance of global inflation on national inflation for 223 countries covering advanced, middle and low income countries over 1980-2012. Along with global inflation, nine country-specific characteristics, such as trade openness, financial development, exchange rate regime and CBI, are considered as they intervene with the effect of global inflation on domestic inflation to a greater or lesser extent. The results suggest that global factors accounts for around $70 \%$ of the variance of inflation in advanced economies ${ }^{16}$, but not in middle- and low-income countries. The global inflation factors are also more important in affecting the national inflation rate in countries with fixed exchange rates. The impact of global inflation on domestic inflation rates is found to be much lower for less developed countries.

Ha et al. (2019) investigate the domestic and global sources of inflation in 26 emerging markets, developing economies and 29 advanced economies over 1970-2017 via factor augmented VAR (FAVAR) models. They conclude that $75 \%$ of variations in inflation is due to domestic shocks, with the most important being supply shocks. However, the importance of supply shocks has declined since 2001 while global demand and oil price shocks became the main drivers among global shocks in affecting inflation. When country-specific characteristics are controlled, the median variation in inflation due to global shocks in countries with greater financial and trade openness and fixed exchange rate regimes was more than two-fold of that in other emerging market and developing economies. After constructing trend inflation and inflation gap by utilizing the Beveridge and Nelson decomposition, Kamber and Wong (2020) analyze 21 emerging markets using FAVAR model ranging from 1990s to 2018 depending on the availability of quarterly data. As foreign shocks, they consider real commodity prices for energy, agricultural commodities, metals and minerals whereas their domestic shocks include inflation inertia, real exchange rate and real GDP. They find that foreign shocks have a larger impact on inflation gap (i.e. transitory components of inflation) than trend inflation (i.e. permanent components of inflation); and note that much of the impact of foreign shocks on inflation gap stems from commodity price shocks. Kamber et al. (2020) study 47 countries including advanced economies (AEs) and EMEs over the period from 1996Q1 to 2018Q3 using hybrid Phillips curve to account for forward- and backward-looking expectations, namely inflation expectations and lagged inflation respectively. Since slope coefficient heterogeneity is allowed, their panel estimation shows that external driving forces, such as foreign output gap and world oil prices, have greater effects in EMEs than AEs; and weight on expected future inflation is lower in EMEs than AEs. Results of the VD analysis suggest that forward- and backward-looking inflation expectations in total explain a great portion of changes in inflation.

\footnotetext{
${ }^{16}$ Those with greater financial development, higher GDP per capita and more central bank transparency.
} 
Table 1

Review Table for Cross-Sectional Analyses

\begin{tabular}{|c|c|c|c|c|}
\hline Paper & Countries & Sample Period & Methodologies & Important Determinants \\
\hline Coorey et al. (1996) & $\begin{array}{l}\text { Transition } \\
\text { countries }\end{array}$ & $1990-1997$ & $\begin{array}{l}\text { Correlation } \\
\text { analysis }\end{array}$ & money supply \\
\hline Catão and Terrones (2001) & EMEs & $1970-2000$ & ARDL & $\begin{array}{l}\text { fiscal deficit, oil price, world } \\
\text { inflation }\end{array}$ \\
\hline IMF (2001) & EMEs & 1970-1999 & $\begin{array}{l}\text { Pooled mean } \\
\text { group (PMG) }\end{array}$ & $\begin{array}{l}\text { fiscal deficit, world inflation, } \\
\text { oil prices }\end{array}$ \\
\hline Loungani and Swagel (2001) & $\begin{array}{l}\text { Developing } \\
\text { countries }\end{array}$ & $1964-1998$ & $\overline{\text { VAR }}$ & $\begin{array}{l}\text { inflation inertia, money } \\
\text { growth, fuel and non-fuel } \\
\text { commodity prices }\end{array}$ \\
\hline Mohanty and Klau (2001) & EMEs & 1970s-1990s & Pooled OLS & $\begin{array}{l}\text { food price, exchange rate, } \\
\text { output gap and excess } \\
\text { money, import prices }\end{array}$ \\
\hline Domaç and Yücel (2005) & EMEs & $1980-2001$ & Pooled probit & $\begin{array}{l}\text { output gap, food production } \\
\text { index, oil prices, autocracy, } \\
\text { durability of the regime }\end{array}$ \\
\hline $\begin{array}{l}\text { Capistrán and Ramos- } \\
\text { Francia (2006) }\end{array}$ & $\begin{array}{l}\text { Latin } \\
\text { American } \\
\text { economies }\end{array}$ & $1980-2006$ & OLS & past inflation \\
\hline Kwon et al. (2006) & $\begin{array}{l}\text { Developing } \\
\text { countries }\end{array}$ & $1963-2004$ & GMM & debt growth \\
\hline Barnichon and Peiris (2007) & SSA & $1960-2003$ & GMM & $\begin{array}{l}\text { output and real money gaps, } \\
\text { excess money }\end{array}$ \\
\hline Borio and Filardo (2007) & EMEs & $1985-2005$ & GLS & $\begin{array}{l}\text { foreign prices, global excess } \\
\text { demand pressures and } \\
\text { factor mobility }\end{array}$ \\
\hline $\begin{array}{l}\text { De Mello and Moccero } \\
(2008)\end{array}$ & $\begin{array}{l}\text { Latin } \\
\text { American } \\
\text { countries }\end{array}$ & $2000-2006$ & GARCH & $\begin{array}{l}\text { expected inflation, interest } \\
\text { rate }\end{array}$ \\
\hline Thorton (2008) & $\begin{array}{l}\text { African } \\
\text { countries }\end{array}$ & $1960-2007$ & OLS, GLS & money growth \\
\hline Habermeier et al. (2009) & $\begin{array}{l}\text { EMEs, } \\
\text { developing } \\
\text { countries }\end{array}$ & $2005-2008$ & $\begin{array}{l}\text { Pooled OLS, } \\
\text { GMM }\end{array}$ & $\begin{array}{l}\text { aggregate demand } \\
\text { pressures, food and energy } \\
\text { prices }\end{array}$ \\
\hline Jongwanich and Park (2009) & $\begin{array}{l}\text { Asian } \\
\text { countries }\end{array}$ & 1996-2009 & $\overline{\text { VAR }}$ & $\begin{array}{l}\text { output gap, inflation } \\
\text { expectations }\end{array}$ \\
\hline $\begin{array}{l}\text { Agénor and Bayraktar } \\
(2010)\end{array}$ & $\begin{array}{l}\text { Middle- } \\
\text { income } \\
\text { developing } \\
\text { countries }\end{array}$ & $1979-2006$ & GMM & $\begin{array}{l}\text { lagged and one lead } \\
\text { inflation rates }\end{array}$ \\
\hline Crowley (2010) & MENACA & $1997-2008$ & $\begin{array}{l}\text { Fixed effect } \\
(\mathrm{FE})\end{array}$ & $\begin{array}{l}\text { inflation inertia, non-fuel } \\
\text { commodity prices }\end{array}$ \\
\hline $\begin{array}{l}\text { Baldini and Poplawski- } \\
\text { Ribeiro (2011) }\end{array}$ & SSA & $1980-2005$ & VAR & money growth \\
\hline
\end{tabular}


Table 1

Review Table for Cross-Sectional Analyses (Continue)

\begin{tabular}{|c|c|c|c|c|}
\hline Paper & Countries & Sample Period & Methodologies & Important Determinants \\
\hline Caceres et al. (2011) & CEMAC & $1996-2010$ & VAR & $\begin{array}{l}\text { controlled prices, } \\
\text { government expenditure, } \\
\text { global food and energy } \\
\text { prices }\end{array}$ \\
\hline Osorio and Unsal (2011) & $\begin{array}{l}\text { Asian } \\
\text { countries }\end{array}$ & $1986-2010$ & GVAR & $\begin{array}{l}\text { commodity prices, output } \\
\text { gap (domestic factors) }\end{array}$ \\
\hline Durevall and Sjö (2012) & $\begin{array}{l}\text { African } \\
\text { countries }\end{array}$ & $1999-2011$ & VECM & past inflation \\
\hline Simpasa et al. (2012) & $\begin{array}{l}\text { African } \\
\text { countries }\end{array}$ & $1961-2010$ & DOLS & $\begin{array}{l}\text { money supply, world food } \\
\text { and oil prices }\end{array}$ \\
\hline Bhattacharya (2013) & Asian EMEs & $2004-2012$ & GMM & import prices, past inflation \\
\hline Oladipo et al. (2013) & $\begin{array}{l}\text { African } \\
\text { countries }\end{array}$ & $1970-2010$ & VAR & $\begin{array}{l}\text { money supply, exchange } \\
\text { rate }\end{array}$ \\
\hline Lim and Sek (2015) & $\begin{array}{l}\text { High inflation } \\
\text { countries }\end{array}$ & $1970-2011$ & ARDL, ECM & $\begin{array}{l}\text { money supply, national } \\
\text { expenditure }\end{array}$ \\
\hline Nguyen et al. (2015) & SSA & $1988-2013$ & GVAR & $\begin{array}{l}\text { exchange rate, monetary } \\
\text { variables and domestic } \\
\text { supply shocks }\end{array}$ \\
\hline Deniz et al. (2016) & EMEs & $2002-2012$ & FE,GMM & inflation inertia \\
\hline Parker (2017) & $\begin{array}{l}\text { Middle and } \\
\text { low income } \\
\text { countries }\end{array}$ & $1980-2012$ & $\begin{array}{l}\text { OLS, dynamic } \\
\text { hierarchical } \\
\text { factor model } \\
\text { (DHFM) }\end{array}$ & $\begin{array}{l}\text { energy and food prices, } \\
\text { domestic factors }\end{array}$ \\
\hline Portillo (2018) & CEMAC & $1998-2007$ & SVAR & $\begin{array}{l}\text { fiscal and commodity price } \\
\text { shocks }\end{array}$ \\
\hline Ha et al. (2019) & $\begin{array}{l}\text { EMEs, } \\
\text { developing } \\
\text { countries } \\
\end{array}$ & $1970-2017$ & $\overline{\text { FAVAR }}$ & $\begin{array}{l}\text { supply shocks, global } \\
\text { demand, oil price }\end{array}$ \\
\hline Kamber et al. (2020) & EMEs & $1996-2018$ & $\begin{array}{l}\text { Random effect } \\
\text { (RE), ARDL }\end{array}$ & $\begin{array}{l}\text { foreign output gap, world } \\
\text { oil prices, inflation inertia }\end{array}$ \\
\hline Kamber and Wong (2020) & EMEs & 1990s-2018 & FAVAR & commodity price shocks \\
\hline
\end{tabular}

\section{Summary and Conclusion}

Although the empirical strategies for examining the dynamics of inflation may vary, the determinants of inflation that have been under consideration in the existing literature on emerging markets and developing countries concentrate mainly on proximate ones. The main findings of these studies can be narrowed down to the followings:

- Inflation is still a monetary phenomenon in emerging markets and developing countries.

- Monetary aggregates either directly (i.e. money supply, money growth) or indirectly (i.e. via government debt, fiscal shocks, demand-pull shocks, regime changes in exchange rate) influence inflation.

- The significance of the monetary variables in explaining inflation depends on both the countries under study and the time horizon, namely, short- or long-run.

- Inflation inertia is a major determinant in understanding inflation variations especially for economies with high inflation rates, specifically more than $10 \%$.

- Although the strong relationship between money and inflation was supported by studies covering the periods until the beginning of 2000s, the analysis on the drivers of inflation has shifted 
towards external effects rather than domestic ones at the beginning

of 2000 s due to the emergence of globally linked economies.

- The presence of open economies, more democratic countries, more independent central banks, trade and monetary unions, transformation from fixed to flexible exchange rate regimes diminished the impacts of domestic factors in explaining inflation, thereby raising those of global determinants.

- Depending on being a member of trade or monetary unions, appreciation/depreciation of the local currency, exchange rate and inflation spillovers and commodity prices became important in identifying variations of inflation.

- Depending on being an exporter or importer in the associated goods, cost-push shocks associated with agroclimatic situations and labor costs; and most importantly, world food, oil and energy prices became significant in understanding inflation dynamics.

The variations in inflation brought by inflation inertia suggest that inflationary expectations and indexations schemes in price and wage are the most critical determinants of inflation dynamics in emerging market and developing economies. Due to the established evidence on backward-looking behavior of inflation inertia, instead of using backward-looking wage settlements, wage negotiations may be aligned on productivity. Inflationary inertia can also be avoided when the monetary authority behaves in a forward-looking manner and becomes more responsive to the deviations of inflation expectations from the inflation target. Credible disinflationary plans and policies may be adopted as they tend to reduce the inflation inertia. Hence, structural reforms and transparent policies, such as inflation targeting, increased credibility in applying policy by the central banks can be regarded as tools for achieving price stability. If the inflation persistence is considered to be due to the staggering of price-indexation and price-setting, especially along with a high public sector deficit, control over the price of public services and consumer goods; and cuts in subsidies may be used in order to suppress the upward pressure on prices.

Since the households in low-income countries spend large proportion of their income on food, government intervention may be required by rationalizing the food consumption and/or prices in order to protect consumers from food price shocks. To prevent the worsening off both the consumers and the producers from oil price shocks, government may set a ceiling in domestic sale price for petroleum products and subsidize production which uses petroleum products as intermediate goods. If the oil price shocks are assumed to be persistent, they may have a second-round effect via cost- and wage-push shocks by affecting inflation expectations. In such cases, central bank interventions may be required by changing short-term interest rates.

The insights from the empirical literature have provided fruitful information for researchers in understanding the sources of inflation; and useful guidance for policy planners in terms of policy implications in targeting inflation and manipulating expectations. Future work still remains to merge this line of research with the theoretical literature as it would allow to identify the repercussion effects of these drivers on inflation; and better gauge welfare effects of policy actions that are implied by the empirical literature. Another future work could be a meta-analysis or a survey for unorthodox models where unconventional monetary policy recommendations can be also delivered.

Due to the nature of the study, informed consent or ethics committee approval was not required. 


\section{References}

Adu, G. and Marbuah, G. (2011). Determinants of inflation in Ghana: An empirical investigation. South African Journal of Economics, 79(3), 251-269. doi: 10.1111/j.1813-6982.2011.01273.x

African Development Bank. (2011). Retrieved from: https://www.afdb.org/en/documents/document/economic-brief-inflation-dynamics-in-selected-eastafrican-countries-ethiopia-kenya-tanzania-and-uganda-26187

Agénor, P.R. and Bayraktar, N. (2010). Contracting models of the Phillips curve empirical estimates for middle-income countries. Journal of Macroeconomics, 32(2), 555-570. doi: 10.1016/j.jmacro.2009.09.002

Alam, Q. and Alam, S. (2016). The Determinants of Inflation in India: The Bounds Test Analysis. International Journal of Economics and Financial Issues, 6(2), 544-550. Retrieved from: https://www.econjournals.com/index.php/ijefi/article/view/2019

Alkoum, A.O.A. and Agil, S.O.S (2013). A study of the factors influencing inflationary pressure in the Libyan economy. Journal of Economics and Finance, 1(6), 35-43. Retrieved from: http://www.iosrjournals.org/iosr-jef/papers/vol1-issue6/G0163543.pdf?id=7861

Antczak, R. (2003). Monetary expansion and its influence on inflation performance in Transition Economies. In M. Dabrowski (Eds.). Disinflation in Transition Economies (pp.37-54), Central European University Press, Budapest. Retrieved from: https://case-research.eu/en/disinflation-in-transition-economies

Baldini, A. and Poplawski-Ribeiro, M. (2011). Fiscal and monetary determinants of inflation in low-income countries: Theory and evidence from Sub-Saharan Africa. Journal of African Economies, 20(3), 419-462. doi: $10.1093 /$ jae/ejr002

Bailliu, J., Garces, D., Kruger, M. and Messmacher, M. (2003). Explaining and forecasting inflation in emerging markets: The case of Mexico. Bank of Canada Working Paper, 2003-17. Retrieved from: https://www.bankofcanada.ca/wp-content/uploads/2010/02/wp03-17.pdf

Bane J. (2018). Dynamics and determinants of inflation in Ethiopia. In Heshmati A., Yoon H. (Eds.) Economic Growth and Development in Ethiopia. Perspectives on Development in the Middle East and North Africa (MENA) Region, 67-84. doi: 10.1007/978-981-10-8126-2_4

Barnichon, R. and Peiris, S.J. (2007). Sources of inflation in Sub-Saharan Africa. IMF Working Paper, No. 07/32. Retrieved from: https://www.imf.org/en/Publications/WP/Issues/2016/12/31/Sources-ofInflation-in-Sub-Saharan-Africa-20196

Bhattacharya, R. (2013). Inflation dynamics and monetary policy transmission in Vietnam and emerging Asia. IMF Working Paper, No. 13/155. Retrieved from: https://www.imf.org/en/Publications/WP/Issues/2016/12/31/Inflation-Dynamics-and-MonetaryPolicy-Transmission-in-Vietnam-and-Emerging-Asia-40734

Blavy, R. (2004). Inflation and monetary pass-through in Guinea. IMF Working Paper, No. 04/223. Retrieved from: https://www.imf.org/en/Publications/WP/Issues/2016/12/31/Inflation-and-Monetary-PassThrough-in-Guinea-17817

Bonato, L. (2007). Money and inflation in the Islamic Republic of Iran. IMF Working Paper, No. 07/119. Retrieved from: https://www.imf.org/en/Publications/WP/Issues/2016/12/31/Money-and-Inflation-inthe-Islamic-Republic-of-Iran-20942

Borio, C. and Filardo, A. (2007). Globalisation and inflation: New cross-country evidence on the global determinants of domestic inflation. BIS Working Papers, No. 227. Retrieved from: https://www.bis.org/publ/work227.htm

Caceres, C., Poplawski-Ribeiro, M. and Tartari, D. (2011). Inflation dynamics in the CEMAC region. IMF Working Paper, No. 11/232. Retrieved from: https://www.imf.org/en/Publications/WP/Issues/2016/12/31/Inflation-Dynamics-in-the-CEMACRegion-25280 
Capistrán, C. and Ramos-Francia, M. (2006). Inflation dynamics in Latin America. Banco de Mexico, The Working Papers, No. 2006-11. Retrieved from: https://ideas.repec.org/p/bdm/wpaper/2006-11.html

Catão, L. and Terrones, M. (2001). Fiscal deficit and inflation: A new look at emerging market evidence. IMF Working Paper, No. 01/74. Retrieved from: https://www.imf.org/external/pubs/ft/wp/2001/wp0174.pdf

Cheng, M.Y. and Tan, H.B. (2002). Inflation in Malaysia. International Journal of Social Economics, 29(5), 411425. doi: $10.1108 / 03068290210423532$

Chiang, S., Lee, C. and Liao, Y. (2021). Exploring the sources of inflation dynamics: New evidence from China. Economic Analysis and Policy, 70, 313-332. doi: 10.1016/j.eap.2021.03.001

Coorey, S., Mecagni, M. and Offerdal, E. (1996). Disinflation in transition economies: The role of relative price adjustment. IMF Working Paper, No. 96/138. Retrieved from: https://www.imf.org/en/Publications/WP/Issues/2016/12/30/Disinflation-in-Transition-EconomiesThe-Role-of-Relative-Price-Adjustment-2099

Crowley, J. (2010). Commodity prices and inflation in the Middle East, North Africa, and Central Asia. IMF Working Paper, No. 10/135. Retrieved from: https://www.imf.org/en/Publications/WP/Issues/2016/12/31/Commodity-Prices-and-Inflation-in-theMiddle-East-North-Africa-and-Central-Asia-23904

Dabrowski, M., Paczynski, W. and Rawdanowicz, L. (2002). Inflation and monetary policy in Russia: Transition experience and future recommendations. Center for Social and Economic Research, 241. Retrieved from: https://case-research.eu/upload/publikacja_plik/sa241.pdf

D'Amato, L. and Garegnani, M.L. (2009). Studying the short-run dynamics of inflation: Estimating a Hybrid New-Keynesian Phillips Curve for Argentina (1993-2007). BCRA Working Papers Series, 200940, Central Bank of Argentina, Economic Research Department. Retrieved from: http://www.bcra.gov.ar/pdfs/investigaciones/WP_2009_40i.pdf

De Mello, L. and Moccero, D. (2009). Monetary policy and inflation expectations in Latin America: Long-Run effects and volatility spillovers. Journal of Money, Credit and Banking, 41(8), 1671-1690. doi: 10.1111/j.1538-4616.2009.00273.x

Deniz, P. Tekçe, M. and Yılmaz, A. (2016). Investigating the determinants of inflation: A panel data analysis. International Journal of Financial Research, 7(2), 233-246. doi: 10.5430/ijfr.v7n2p233

Diouf, M.A. (2007). Modeling inflation for mali. IMF Working Paper, No. 07/295. Retrieved from: https://www.imf.org/en/Publications/WP/Issues/2016/12/31/Modeling-Inflation-for-Mali-21518

Domaç, I. and Yücel, E.M. (2005). What triggers inflation in emerging market economies?. Review of World Economics/ Weltwirtschaftliches Archiv, 141(1), 141-164. Retrieved from: https://www.jstor.org/stable/40441038

Duma, N. (2008). Pass-Through of external shocks to inflation in Sri Lanka. IMF Working Paper, No. 08/78. Retrieved from: https:/www.imf.org/en/Publications/WP/Issues/2016/12/31/Pass-Through-ofExternal-Shocks-to-Inflation-in-Sri-Lanka-21837

Durevall, D. and Sjö, B. (2012). The dynamics of inflation in Ethiopia and Kenya. African Development Bank Working Paper Series, No. 151, Tunis, Tunisia. Retrieved from: https://www.afdb.org/en/documents/document/working-paper-151-the-dynamics-of-inflation-inethiopia-and-kenya-28935

Durevall, D., Loening, J.L. and Birru Y.A. (2013). Inflation dynamics and food prices in Ethiopia. Journal of Development Economics, 104, 89-106. doi: 10.1016/j.jdeveco.2013.05.002

Fischer, S., Sahay, R. and Vegh, C.A. (1998). From transition to market: Evidence and growth prospects. IMF Working Paper, No. 98/52. Retrieved from: https://www.imf.org/en/Publications/WP/Issues/2016/12/30/From-Transition-to-Market-Evidenceand-Growth-Prospects-2549 
Fisher, S. Sahay, R. and Vegh, C. (2002). Modern hyper- and high inflations. Journal of Economic Literature, 40(3), 837-80. Retrieved from: https://www.jstor.org/stable/3217111

Gottschalk, J., Kalonji, K. and Miyajima, K. (2008). Analyzing determinants of inflation when there are data limitation: The case of Sierra Leone. IMF Working Paper, No. 08/271. Retrieved from: https://www.imf.org/en/Publications/WP/Issues/2016/12/31/Analyzing-Determinants-of-InflationWhen-There-Are-Data-Limitation-The-Case-of-Sierra-Leone-22520

Grigorian, D., Khachatryan, A. and Sargsyan, G. (2004). Exchange rate, money, and wages: What is driving prices in Armenia?. IMF Working Paper, No. 04/229. Retrieved from: https://www.imf.org/en/Publications/WP/Issues/2016/12/31/Exchange-Rate-Money-and-WagesWhat-is-Driving-Prices-in-Armenia-17826

Ha, J., Kose, M.A. and Ohnsorge, F. (2019). Inflation in emerging and developing economies: Evolution, drivers and policies. Washington, DC: World Bank. Retrieved from: https://openknowledge.worldbank.org/handle/10986/30657

Habermeier, K., Ötker-Robe, I., Jacome, L., Giustiniani, A., Ishi, K., Vavra, D., Kisinbay, T. and Vazquez, F. (2009). Inflation pressures and monetary policy options in emerging and developing countries-a cross regional perspective. IMF Working Paper, No. 09/1. Retrieved from: https://www.imf.org/en/Publications/WP/Issues/2016/12/31/Inflation-Pressures-and-MonetaryPolicy-Options-in-Emerging-and-Developing-Countries-A-Cross-22496

Hoggarth, G. (1996). Monetary Policy in Russia. In Jouko Rautava (Eds.), Russia's Financial Markets and the Banking Sector in Transition (pp. 53-82), Bank of Finland Studies A: 95, Helsinki. Retrieved from: https://helda.helsinki.fi/bof/handle/123456789/9436

International Monetary Fund. (2001). Retrieved from: https://www.elibrary.imf.org/view/IMF081/079999781589060326/07999-9781589060326/ch04.xml?rskey=aNewqU\&result=6\&redirect=true

International Monetary Fund. (2003). Retrieved from: https://www.elibrary.imf.org/view/IMF081/080079781589062832/08007-9781589062832/ch03.xml

International

Monetary

Fund.

(2008). Retrieved

from: https://www.imf.org/en/Publications/WEO/Issues/2016/12/31/World-Economic-Outlook-

October-2008-Financial-Stress-Downturns-and-Recoveries-22028

Iwasaki, I. and Uegaki, A. (2017). Central bank independence and inflation in transition economies: A comparative meta-analysis with developed and developing economies. Eastern European Economics, 55(3), 197-235. doi: 10.1080/00128775.2017.1287548

Jongwanich, J. and Park, D. (2009). Inflation in developing Asia. Journal of Asian Economics, 20(5), 507-518. doi: 10.1016/j.asieco.2009.07.004

Kamber, G. and Wong, B. (2020). Global factors and trend inflation. Journal of International Economics, 122, 103265. doi: 10.1016/j.jinteco.2019.103265

Kamber, G., Mohanty, M. and Morley, J. (2020). What drives inflation in advanced and emerging market economies? BIS Paper No. 111a. Retrieved from: https://ssrn.com/abstract=3575893

Khan, M.S. and Schimmelpfennig, A. (2006). Inflation in Pakistan: Money or wheat?. IMF Working Paper, No. 06/60. Retrieved from: https://www.imf.org/en/Publications/WP/Issues/2016/12/31/Inflation-inPakistan-Money-or-Wheat-18793

Khan, R.E.A. and Gill, A.R. (2010). Determinants of inflation: A case of Pakistan (1970-2007). Journal of Economics, 1(1), 45-51. doi: 10.1080/09765239.2010.11884923

Kinda, T. (2011). Modeling inflation in Chad. IMF Working Paper, No. 11/57. Retrieved from: https://www.imf.org/en/Publications/WP/Issues/2016/12/31/Modeling-Inflation-in-Chad-24705 
Klein, N. and Kyei, A. (2009). Understanding inflation inertia in Angola. IMF Working Paper, No. 09/98. Retrieved from: https://www.imf.org/en/Publications/WP/Issues/2016/12/31/Understanding-InflationInertia-in-Angola-22922

Koen, V. and Marrese, M. (1995). Stabilization and structural change in Russia, 1992-94. IMF Working Paper, No. 95/13. Retrieved from: https://www.imf.org/en/Publications/WP/Issues/2016/12/30/Stabilizationand-Structural-Change-in-Russia-1992-94-1852

Korhonen, I. (1998). An error-correction model of prices, money, output and interest rate in Russia. Review of Economies in Transition, 5, 33-44. Retrieved from: https://helda.helsinki.fi/bof/handle/123456789/12903

Kutan, A.M. and Brada J.C. (1999). The end of moderate inflation in three transition economies?. Federal Reserve Bank of St. Louis., Working Papers 1999-003, Retrieved from: https://ideas.repec.org/p/fip/fedlwp/1999-003.html

Kwon, G., McFarlane, L. and Robinson, W. (2006). Public debt, money supply, and inflation: A cross-country study and its application to Jamaica. IMF Working Paper, No. 06/121. Retrieved from: https://www.imf.org/en/Publications/WP/Issues/2016/12/31/Public-Debt-Money-Supply-andInflation-A-Cross-Country-Study-and-Its-Application-to-Jamaica-19133

Lim, C.H. and Papi, L. (1997). An econometric analysis of the determinants of inflation in Turkey. IMF Working Paper, No. 97/170. Retrieved from: https://www.imf.org/external/pubs/ft/wp/wp97170.pdf

Lim, Y.C. and Sek, S.K. (2015). An Examination on the determinants of inflation. Journal of Economics, Business and Management, 3(7), 678-682. Retrieved from: http://www.joebm.com/papers/265E10010.pdf

Lissovolik, B. (2003). Determinants of inflation in a transition economy: The case of Ukraine. IMF Working Paper, No. 03/126. Retrieved from: https://www.elibrary.imf.org/doc/IMF001/016889781451854923/01688-9781451854923/Other_formats/Source_PDF/01688-9781451900170.pdf

Loungani, P. and Swagel, P. (2001). Sources of inflation in developing countries. IMF Working Paper, No. 01/198. Retrieved from: https://www.imf.org/external/pubs/ft/wp/2001/wp01198.pdf

Mohanty, D. and John, J. (2015). Determinants of inflation in India. Journal of Asian Economics, 36, 86-96. doi: 10.1016/j.asieco.2014.08.002

Mohanty, M.S. and Klau, M. (2001). What determines inflation in emerging market countries?. In Bank for International Settlements (Eds.), Modeling Aspects of the Inflation Process and Monetary Transmission Mechanism in Emerging Market Countries (pp.1-38), BIS Papers No. 8, Bank for International Settlements. Retrieved from: https://ideas.repec.org/h/bis/bisbpc/08-01.html

Monfort, B. and Peña, S. (2008). Inflation determinants in Paraguay: Cost push versus demand pull factors. IMF Working Paper, No. 08/270. Retrieved from: https://www.imf.org/en/Publications/WP/Issues/2016/12/31/Inflation-Determinants-in-ParaguayCost-Push-versus-Demand-Pull-Factors-22505

Moser, G.G. (1995). The main determinants of inflation in Nigeria. IMF Staff Papers, 42(2), 270-289. Retrieved from: https://www.jstor.org/stable/3867573

Nassar, K. (2005). Money demand and inflation in Madagascar. IMF Working Paper, No. 05/236. Retrieved from: https://www.imf.org/en/Publications/WP/Issues/2016/12/31/Money-Demand-and-Inflation-inMadagascar-18746

Nikolic, M. (2000). Money growth-inflation relationship in postcommunist Russia. Journal of Comparative Economics, 28(1), 108-133. doi: 10.1006/jcec.1999.1629

Nguyen, A.D.M, Dridi, J., Unsal, D.F. and Williams, O.H. (2015). On the drivers of inflation in Sub-Saharan Africa. IMF Working Paper, No. 15/189. Retrieved from: https://www.imf.org/external/pubs/ft/wp/2015/wp15189.pdf 
Oladipo, O.S., Ntoko, A. and Forrester, W. (2013). Sources of inflation in developing countries: Evidence from some West African countries. Advances in Management and Applied Economics, 3(2), 83-102. Retrieved from: http://www.scienpress.com/Upload/AMAE\%2fVol\%203_2_4.pdf

Osorio, C. and Unsal, D.F. (2011). Inflation dynamics in Asia: Causes, changes, and spillovers from China. IMF Working Paper, No. 11/257. Retrieved from: https://www.imf.org/en/Publications/WP/Issues/2016/12/31/Inflation-Dynamics-in-Asia-CausesChanges-and-Spillovers-From-China-25333

Parker, M. (2017). Global inflation: the role of food, housing and energy prices. European Central Bank, Working Paper Series, No. 2024. Retrieved from: https://www.ecb.europa.eu/pub/pdf/scpwps/ecbwp2024.en.pdf

Patnaik, A. (2010). Study of inflation in India: A cointegrated vector autoregressive approach. Journal of Quantitative Economics, 8(1), 118-129. Retrieved from: https://ideas.repec.org/a/jqe/jqenew/v8y2010i1p118-129.html

Pavlavani, M. and Rahimi, M. (2009). Sources of inflation in Iran: An application of ARDL approach. International Journal of Applied Econometrics and Quantitative Studies, 9(1), 61-76. Retrieved from: http://www.usc.es/economet/reviews/ijaeqs914.pdf

Portillo, R. (2018). A Structural Analysis of the Determinants of Inflation in the CEMAC Region. In Berg, A. and Portillo, R. (Eds.) Monetary Policy in Sub-Saharan Africa (pp .419-435), Oxford Scholarship Online. doi: 10.1093/oso/9780198785811.003.0020

Sargent, T.J. and Wallace, N. (1981). Some unpleasant monetarist arithmetic. Federal Reserve Bank of Minneapolis Quarterly Review, 5(3), 1-17. Retrieved from: https://www.minneapolisfed.org/research/qr/qr531.pdf

Siliverstovs, B. and Bilan, O. (2005). Modeling inflation dynamics in transition economies: the Case of Ukraine. Eastern European Economics, 43(6), 66-81. doi: 10.2753/EEE0012-8755430604

Thorton, J. (2008). Money, output and inflation in African economies. South African Journal of Economics, 76(3), 356-366. doi: 10.1111/j.1813-6982.2008.00199.x

Ubide, A. (1997). Determinants of inflation in Mozambique. IMF Working Paper, No. 97/145. Retrieved from: https://www.imf.org/external/pubs/ft/wp/wp97145.pdf

Wen, F., Min, F., Zhang, Y.J. and Yang, C. (2019). Crude oil price shocks, monetary policy, and China's economy. International Journal of Finance \& Economics, 24(2), 812-827. doi: 10.1002/ijfe. 1692

Williams, O. and Adedeji, O.S. (2004). Inflation Dynamics in the Dominican Republic. IMF Working Paper, No. 04/29. Retrieved from: https://www.imf.org/external/pubs/ft/wp/2004/wp0429.pdf

Wolde-Rufael, Y. (2008). Budget deficits, money and inflation: The case of Ethiopia. The Journal of Developing Areas, 42(1), 183-199. Retrieved from: https://www.jstor.org/stable/40376201 


\section{Genişletilmiş Özet}

\section{Amaç}

$\mathrm{Bu}$ makalenin amacı, kısıtlı geçmişe sahip olan gelişmekte olan ülkeler ile yükselen piyasa ekonomilerinde, genel olarak 'yakın' belirleyiciler olarak adlandırılan enflasyon etkenleri hakkında değerli olan temel bilgileri ve ortak gerçekleri, gelecek araştırmalara ve politika yapıcılara sağlamak için ampirik çalışmaları gözden geçirmek ve mevcut literatürün sonuçlarından ortaya çıan örüntüleri özetlemektir.

\section{Tasarım ve Yöntem}

Derleme türündeki bu çalışma, geçmişten günümüze enflasyon dinamiklerini anlamaya yardımcı olan etkenleri konu alan ampirik çalışmalardaki örneklem, zaman aralığı, belirleyici seçimleri, tahmin yöntemleri ve ana bulguları özetleyerek ilerler.

\section{Bulgular}

Enflasyon, bu ülkelerdeki doğrudan veya dolaylı itici güçlerden kaynaklanan, temelde parasal bir olgudur. Bununla birlikte, parasal büyüklüklerin etkilerinin önemi, incelenen ülkelere ve dönemlere bağlıdır. Enflasyonun sürekliliği enflasyonu açıklamada önemli bir belirleyicidir ve bu, söz konusu ülkeler için enflasyon dinamiklerinde geriye dönük bir davranış olduğunu düşündürmektedir. Son olarak, enflasyonu anlamada yerel belirleyicilerin öneminin dışsal belirleyicilere doğru kayması, son yirmi yılda küresel belirleyicilerin enflasyonu anlamada daha büyük bir rol oynadığına işaret etmektedir.

\section{Sınırlılıklar}

Çalışmada, alışılmışın dışında modeller ve teorilere odaklanılmadığından, alışılmadık para politikası önerileri sunulması söz konusu olabilecek kriz dönemlerine dair örüntüler bulunmamaktadır. Ancak bu, gelecek çalışma olarak düşünülmüştür.

\section{Öneriler (Teorik, Uygulama ve Sosyal)}

Enflasyon ataletini azaltmak için para otoritesi, ileriye dönük davranabilir, güvenilir enflasyonla mücadele politikaları benimseyebilir, yapısal reformlara hız verebilir. Tüketicileri, gıda fiyat şoklarından korumak için hükümet, gıda fiyatlarını rasyonelleştirebilir. Hem tüketicilerin hem de üreticilerin petrol fiyat şoklarından olumsuz etkilenmesini önlemek için hükümet, petrol ürünleri için yurt içi satış fiyatına tavan uygulaması koyabilir.

\section{Originality/Value}

$\mathrm{Bu}$ çalışmanın literatüre üç yönden katkısı vardır. Birincisi, enflasyon dinamiklerini anlamaya yönelik makaleleri bir araya getirmek ve bu konudaki bilgi boşluklarına işaret ederek gelecek çalışmalar için bir arka plan sağlamak. İkincisi, bu ülkelerin, ülkeye ve zamana bağlı sonuçlarını gözler önüne sermek ve sanayileşmiş ülkelere kıyasla gelişmekte olan ülkeler ve yükselen pazarlarda bu araştırma hattının ne kadar olgunlaşmamış olduğunu ortaya koymak. Son olarak, bu ülkelerin para politikası yapıcılarına politika önerileri sunmak.

Araştırmacı Katkısı: Dila ASFUROĞLU (\%100). 